\title{
EFFECT OF THERMOCYCLING ON THE TENSILE AND SHEAR BOND STRENGTHS OF THREE SOFT LINERS TO A DENTURE BASE RESIN
}

\author{
Carlos Nelson ELIAS ${ }^{1}$, Flavio Queiroz HENRIQUES ${ }^{2}$
}

1- DSc, Professor at Materials Science Department, Military Institute of Engineering Rio de Janeiro, RJ - Brazil.

2- MSc, Private Clinic, Copacabana, Rio de Janeiro, RJ - Brazil.

Corresponding address: Flavio Queiroz Henriques - Rua Joaquim Nabuco, 43, Copacabana - Rio de Janeiro - RJ - e-mail: fqhestetica@oi.com.br

Received: November 08, 2004 - Modification: February 02, 2006 - Accepted: February 12, 2007

\begin{abstract}
S

tatement of problem. In clinical practice, loss of adhesion between the silicone-based denture liner and the denture base resin is always an undesirable event that might cause loss of material softness, water sorption, bacterial colonization and functional failure of the prosthesis.

Purpose. This study evaluated the effect of thermocycling on tensile and shear bond strengths of three soft liner materials to a denture base acrylic resin.

Material and methods. Three resilient liners (Mucopren-Soft, Mollosil-Plus and Dentusil) and a heat-polymerized acrylic resin (QC-20) were processed according to manufacturers' directions. Sixty specimens (14 x $14 \mathrm{~mm}$ cross-sectional area) per bond strength test ( 20 for each liner) were fabricated and either stored in water at $37^{\circ} \mathrm{C}$ for 24 hours (control groups; $\mathrm{n}=10$ ) or thermocycled 3,000 times in water between $5^{\circ} \mathrm{C}$ and $55^{\circ} \mathrm{C}$ (test groups; $\mathrm{n}=10$ ). The specimens were tested in tensile and shear strength in a universal testing machine until fracture. Bond strength means were compared between water-stored and thermocycled groups for each material, as well as among materials for each treatment (water storage or thermocycling). Failure mode (adhesive, cohesive and mixed) after debonding was assessed. Data were analyzed statistically by paired Student's t-test and ANOVA at 5\% significance level.

Results. The water-stored groups had statistically significant higher bond strengths than the thermocycled groups ( $\mathrm{p}<0.05)$. Without thermocycling, Mucopren-Soft $(2.83 \pm 0.48 \mathrm{MPa})$ had higher bond strength than Mollosil-Plus $(1.04 \pm 0.26 \mathrm{MPa})$ and Dentusil $(1.14 \pm 0.51 \mathrm{MPa})$. After thermocycling, Mucopren-Soft $(1.63 \pm 0.48 \mathrm{MPa})$ had the highest bond strength $(\mathrm{p}<0.05)$.

Conclusion. The bond strength of the three soft denture liners tested in this study changed with their chemical composition and all of them exhibited higher bond strengths than those usually reported as clinically acceptable.

Clinical Implications. All soft lining materials tested in this study showed a significant decrease in the bond strength to an acrylic denture base resin after thermocycling. In spite of thermocycling, though, the silicone-based liners had satisfactory bond strengths for clinical application.
\end{abstract}

Uniterms: Thermocycling; Soft denture liners; Shear bond strength; Tensile strength; Denture base resin.

\section{INTRODUCTION}

Although the causes of failure of denture liners are known, failure prevention is still a challenge. It is important that dental prostheses present a uniform loading distribution and incidence of low forces on the supporting tissues. Excess stress on the denture-bearing tissue causes bone resorption and traumatic ulceration. Soft denture liners have been used as cushions between the hard denture base and denture-bearing tissue. These materials are also indicated for patients with mucosal sensitivity and discomfort ${ }^{1}$. Soft liners have a viscoelastic behavior after stress application that allows load reduction and redistribution over a larger area.

There are two established types of soft liners ${ }^{1}$ : the socalled soft acrylics and silicone elastomers. Theses materials are polymerized at room temperature or at higher temperatures ${ }^{1}$. The resilient lining materials are classified as temporary or soft permanent. The temporary materials are used for a limited period, approximately 7 days, to aid the healing of the tissues in contact with the denture. Soft permanent or long-term materials are used on complete dentures where it is necessary to absorb masticatory loads, and are indicated for patients who are unable to tolerate the pressures transmitted by the denture to the underlying mucosa of the edentulous ridge ${ }^{9}$. 
The choice for a soft liner for clinical use should be based on the material's biocompatibility, mechanical properties and durability in the oral environment. However, these lining materials may present physical and mechanical problems during clinical application such as color alteration, loss of plasticizer and resilience, poor rupture strength and porosity ${ }^{5}$.

It is well known that under clinical conditions, the most frequent reason of resilient liner failure is loss of adhesion to the denture base. The tensile bond strength of silicone liners ${ }^{3,5,6,8}$ has been extensively investigated and it is well known that water reduces adhesion and causes liner degradation. The findings of a previous study ${ }^{3}$ showed that the tensile bond strength of two denture resilient lining materials was not affected by immersion in a denture cleanser.

During mastication, the oral cavity gets in contact with foods at different temperatures. The most critical effect of temperature is due to chewing of hot foods and drinking of cold fluids, and temperature changes may affect the bonding at liner-denture base resin interface. While some authors ${ }^{6,8}$ have reported that thermocycling decreases the tensile bond strength of denture liners, data are lacking about the effect of thermocycling on shear strength, which is more critical than tensile loading. Therefore, the purpose of this study was to evaluate the effect of thermocycling on the tensile and shear bond strengths of three soft liner materials to a denture base resin as well as to characterize the failure mode.

\section{MATERIALAND METHODS}

Three silicone-based, resilient denture liners were applied to a heat-polymerized denture base acrylic resin (Table 1) to assess the tensile and shear bond strengths at the linerdenture base resin interface as well as the failure mode after deboding.

Sixty specimens per bond strength test (20 for each denture liner) were fabricated in moulds $(8.0 \mathrm{~cm} \times 1.0 \mathrm{~cm} \times 0.2$ $\mathrm{cm}$ ) constructed using a conventional dental flasking technique.

For tensile bond strength test, 20 aluminum bars ( $40 \mathrm{~mm}$ long; $40 \mathrm{~mm}$ wide; and $14 \mathrm{~mm}$ thick) were machined and polished and 1 aluminum spacer bar (300 mm long; $14 \mathrm{~mm}$ wide; and $3 \mathrm{~mm}$ thick) was cut and polished. The aluminum bars and spacer were invested in silicone rubber to allow easy removal of the processed specimens from the die. The aluminum bars were put top-to-top inside the die and separated by the spacer bar (Figure 1). The die was filled with gypsum and after setting the aluminum bars were removed from the die leaving only the spacer bar. QC-20 acrylic resin was mixed according to the manufacturer's instructions, poured into the mold and processed in a water bath at $75^{\circ} \mathrm{C}$ for 9 hours. After polymerization, the aluminum spacer and acrylic specimens were removed and the acrylic resin bars were trimmed. The surface to be bonded was smoothed using 240-grit silicone carbide paper, cleaned, dried and treated according to the instructions each silicone liner's manufacturer (Table 1). The acrylic resin specimens were placed back into the die in the same position as that of fabrication. The liner was packed into the space remaining after spacer removal, the mold was reassembled and the liner was processed according to the manufacturers' directions. Thereafter, the specimens were removed from the die, smoothed with 240-grit silicone carbide paper and had their dimensions recorded.

For shear bond strength test, the specimens were prepared in the same way as described above, except for the fact that the acrylic bars were placed side-by-side in the die and the aluminum space bar measured $3 \times 3 \times 2 \mathrm{~mm}$ (Figure 2).

For each soft liner/resin combination, the specimens were either stored in water at $37^{\circ} \mathrm{C}$ for 24 hours $(n=10$; control groups) or submitted to a thermocycling regimen of 3,000 cycles in a home built thermocycler system $(n=10$; test groups). Thermocycling alternated between $5^{\circ} \mathrm{C}$ and $55^{\circ} \mathrm{C}$ waterbaths. Dwell time was 1 minute $^{8}$.

The water-stored and thermocycled specimens were tested in tensile and shear strength in a universal testing machine DL10000 (Emic Equipamentos e Sistemas de Ensaios, São José dos Pinhais, PR, Brazil) at a crosshead speed of $5 \mathrm{~mm} / \mathrm{min}$ until fracture. The rupture peak load was recorded. Tensile bond strength in MPa was calculated by dividing this load $(N)$ by the specimen cross-sectional area $\left(\mathrm{mm}^{2}\right)$ close to the debonding site. Shear bond strength was calculated in the same way, except for the fact that the adhesive area was divided by the peak load. Figures 3 and 4 illustrate the tensile/shear bond strength testing machine.

The debonded surfaces were examined under X10

TABLE 1- Silicone-based resilient liners and denture base resin tested in this study

\begin{tabular}{|c|c|c|c|}
\hline Material & Composition and cure type & Batch No. & Manufacturer \\
\hline Mucopren Soft & Polyvinylsiloxane & 000515 & $\begin{array}{l}\text { Kettenbach GmbH \& Co, } \\
\text { Eschenburg, Germany }\end{array}$ \\
\hline Mollosil Plus & $\begin{array}{l}\text { Polydimethylsiloxane. } \\
\text { Auto-polymerized silicone rubber }\end{array}$ & 001005 & Detax GmbH, Ettlingen, Germany \\
\hline Dentusil & Polyvinylsiloxane & 0004-204 & Bosworth, Skokie, II \\
\hline QC-20 & Heat-polymerized acrylic resin & $\begin{array}{l}65279 \text { powder/ } \\
63335 \text { liquid }\end{array}$ & Dentsply Int Inc., York, Pa \\
\hline
\end{tabular}




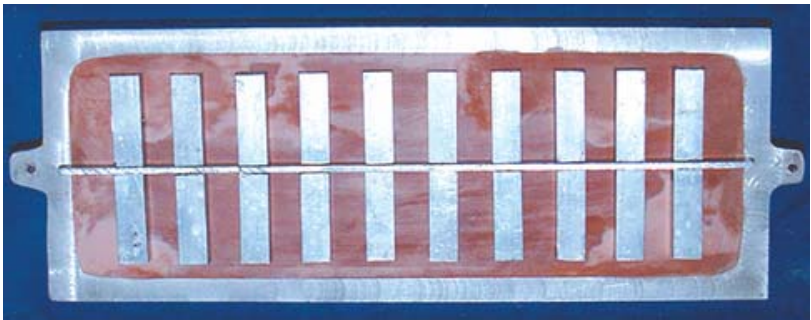

FIGURE 1- Aluminum bars and spacer in the mold used for fabrication of tensile strength specimens

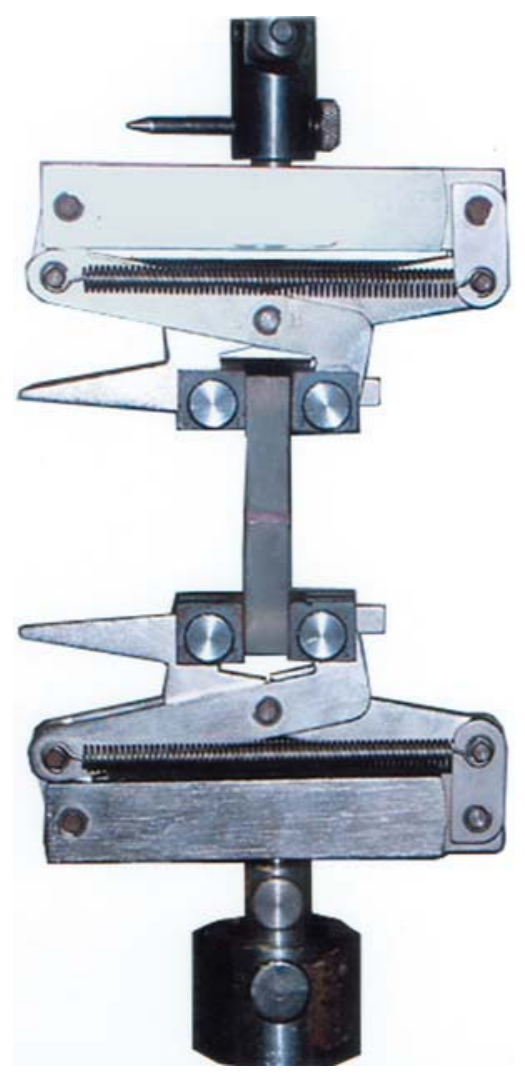

FIGURE 3- Tensile strength specimen in the universal testing machine

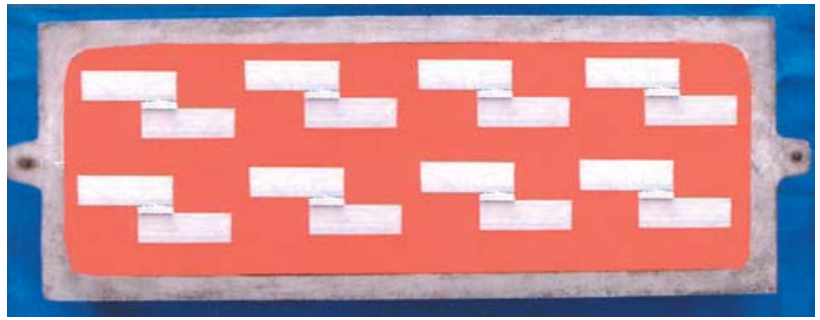

FIGURE 2-Aluminum bars and spacer in the mold used for fabrication of shear strength specimens

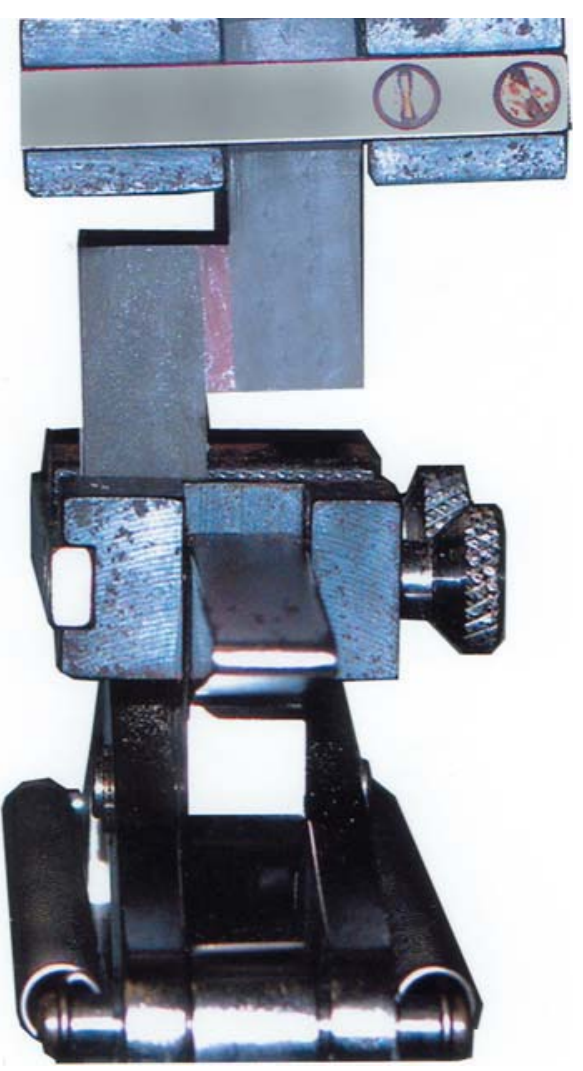

FIGURE 4- Shear strength specimen in the universal testing machine

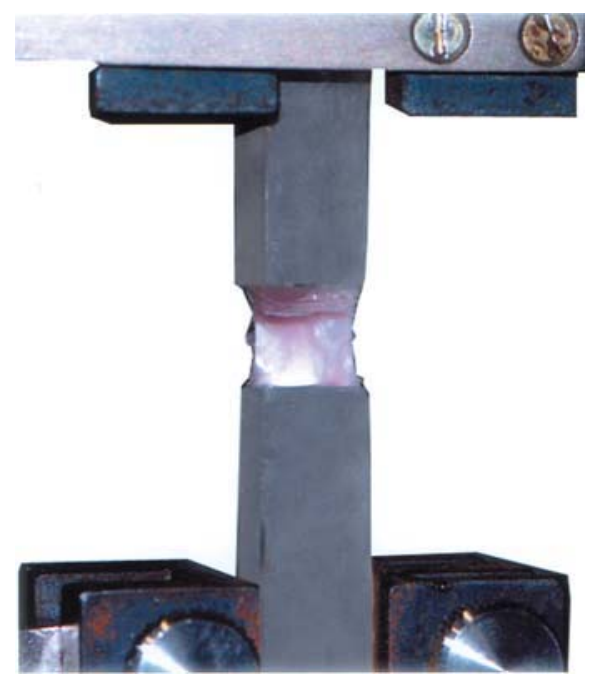

FIGURE 5- Specimen during tensile bond strength testing 
magnification to assess the failure modes, which were classified as adhesive, cohesive or mixed. Adhesive failure was considered the one at the liner/resin interface; cohesive failure if fracture occurred totally within the liner material; and mixed failure was assigned when both failure modes were observed ${ }^{6}$.

\section{RESULTS}

Tensile and shear bond strength means for the waterstored and thermocycled groups are shown on Tables 2 and 3 , respectively.

In all groups, tensile bond strength means were higher than shear bond strength means. Although thermocycling had a deleterious effect on shear bond strength as well, the decrease in bond strength was less accentuated than that observed under tensile loading. Statistical analysis by paired
Student's t-test showed that thermocycling did not reduce significantly the shear bond strength of Dentusil ( $p>0.05)$. Mucopren Soft and Mollosil-Plus were both significantly affected by thermocycling, which reduced their shear bond strength by $28 \%(\mathrm{p}=0.022)$ and $33 \%(\mathrm{p}=0.008)$, respectively

Percent failure mode frequency after debonding for each tested condition is given on Table 4 . It was observed that thermocycling increased the occurrence of mixed failure mode. Figure 5 shows a specimen during tensile strength testing, in which it is possible to notice a good union between the silicone-based liner and the acrylic resin.

\section{DISCUSSION}

While the effect of thermocycling on the tensile properties of silicone-based denture liners has been investigated $^{3,5,6,8}$, there is lack of reports on shear strength

TABLE 2- Tensile bond strength (MPa) means ( \pm standard deviation) for the water-soaked and thermocycled groups $(\mathrm{N}=60)$

\begin{tabular}{|c|c|c|c|c|c|c|}
\hline & \multicolumn{3}{|c|}{ Water-soaking } & \multicolumn{3}{|c|}{ Thermocycling } \\
\hline & Min & Max & Means ( \pm SD) & Min & Max & Means ( $( \pm S D)$ \\
\hline Mucopren Soft & 1.84 & 3.06 & $2.83 \pm 0.48$ & 1.03 & 2.05 & $1.63 \pm 0.48$ \\
\hline Mollosil Plus & 0.78 & 1.46 & $1.04 \pm 0.26$ & 0.57 & 0.80 & $0.72 \pm 0.10$ \\
\hline Dentusil & 0.49 & 1.90 & $1.14 \pm 0.51$ & 0.49 & 1.83 & $0.97 \pm 0.51$ \\
\hline
\end{tabular}

$\mathrm{n}=10$ specimens per experimental condition.

TABLE 3- Shear bond strength (MPa) means ( \pm standard deviation) for the water-soaked and thermocycled groups $(\mathrm{N}=60)$

\begin{tabular}{|c|c|c|c|c|c|c|}
\hline & \multicolumn{3}{|c|}{ Water-soaking } & \multicolumn{3}{|c|}{ Thermocycling } \\
\hline & Min & Max & Means ( $\pm S D$ ) & Min & Max & Means ( $\pm S D$ ) \\
\hline Mucopren Soft & 2.35 & 3.41 & $2.84 \pm 0.53$ & 1.39 & 2.64 & $2.13 \pm 0.46$ \\
\hline Mollosil Plus & 0.85 & 1.27 & $1.04 \pm 0.04$ & 0.45 & 1.90 & $0.81 \pm 0.42$ \\
\hline Dentusil & 0.59 & 0.96 & $0.81 \pm 0.02$ & 0.61 & 1.03 & $0.78 \pm 0.04$ \\
\hline
\end{tabular}

$\mathrm{n}=10$ specimens per experimental condition.

TABLE 4- Failure mode frequency (\%) after debonding

\begin{tabular}{|c|c|c|c|c|c|c|c|}
\hline & \multirow[b]{2}{*}{ Bond strength test } & \multicolumn{3}{|c|}{ Water-soaking } & \multicolumn{3}{|c|}{ Thermocycling } \\
\hline & & Adhesive & Cohesive & Mixed & Adhesive & Cohesive & Mixed \\
\hline \multirow[t]{2}{*}{ Mucopren Soft } & Tensile & 20 & 60 & 20 & 40 & - & 60 \\
\hline & Shear & 80 & - & 20 & 40 & - & 60 \\
\hline \multirow[t]{2}{*}{ Mollosil Plus } & Tensile & 60 & 20 & 20 & 100 & - & - \\
\hline & Shear & 20 & 60 & 20 & 60 & - & 40 \\
\hline \multirow[t]{2}{*}{ Dentusil } & Tensile & 60 & - & 40 & 40 & - & 60 \\
\hline & Shear & 20 & 60 & 20 & 20 & 40 & 40 \\
\hline
\end{tabular}


testing, although shear loading is a more critical stress than tensile loading. The results of the present study showed that tensile strength of soft liners to a denture base resin was higher than shear strength and that thermocycling decreased liner-to-denture bond strength. These finings indicate that the adhesive interface was less resistant to shear loading than to tensile loading.

It has been reported that the bonding between resilient lining materials and denture base materials is affected by aging in water, the nature of the denture base material and the temperature ${ }^{5,6,8}$. Resilient denture liners immersed in water leach out plasticizers and absorb water. These two mechanisms affect the denture compliance and dimensional stability ${ }^{6}$. The material becomes brittle and the external load is transferred to the interface. In the present study, all thermocycled groups showed significantly lower bond strength than the water-stored groups. This outcome may be attributed to material's thermal aging and water sorption at the interface between the soft liners and denture base material.

Regarding the three silicone-based denture liners tested in this study, it was observed that Mucropen Soft and Mollosil-Plus stored in water had statistically significant higher bond strengths than after thermocycling $(\mathrm{p}=0.01)$. While the tensile bond strengths of Mucropren Soft were reduced in 54\% ( $\mathrm{p}=0.01)$, Mollosil-Plus had its tensile bond strength decreased in $39 \%(p<0.05)$ after the thermocycling regimen. On the other hand, the tensile bond strength of Dentusil soft liner was not statistically affected by thermocycling $(\mathrm{p}<0.68)$, showing a decrease of only $17 \%$. Dentusil probably absorbed less water than Mollosil-Plus. The decrease in bond strength may be attributed to swelling and stress concentration at the bonding interface or to changes in the viscoelatic properties of the lining material. The results of this study contradict those of a previous work ${ }^{6}$, which reported that tensile bond strength of Mollosil increased after thermocycling.

The water-stored Mollosil Plus and Dentusil groups had predominantly adhesive failures after tensile testing, while cohesive failures were the most common fracture pattern in the water-stored Mucopren Soft group. These results indicate that, in most cases, the adhesive resistance at the liner-denture base resin interface was lower than that of the silicone-based lining materials. The opposite was observed after thermocycling, which seemed to affect the tensile strength of the liners. The mechanical properties of polymers increase with aging. In the present study, thermocycling induced the aging of the silicone-based lining materials, and increased their tensile bond strength, which was higher than that of the adhesive interface. Table 4 shows that after tensile strength testing, the thermocycled groups exhibited predominantly adhesive- or mixed-failure modes, which show that the interfacial bond strength of Mollosil and Dentusil was lower than that of the silicone-based materials.

After shear testing of the water-stored groups, a cohesive-failure mode was predominantly observed for Mucopren Soft while an adhesive failure was the most frequent for the other lining materials. Among the thermocycled groups, a diverse fracture pattern was observed after shear testing. Most Mucopren Soft specimens showed a mixed-failure mode without cohesive rupture; the majority of Dentusil specimens had cohesive failures after fracture and no case of adhesive failure; and Mollosil Plus showed an equal number adhesive, cohesive and mixed failures.

Tables 2 and 3 show the relation between debonding stress and failure mode. After tensile testing, water-stored Mucopren-Soft groups presented 20\% adhesive failure, $60 \%$ cohesive failure and $20 \%$ mixed failure, while in the thermocycled groups, the results changed to $40 \%$ adhesive and $60 \%$ mixed modes. Water-stored Mollosil groups had the following percent failure modes: $60 \%$ adhesive, $20 \%$ cohesive and $20 \%$ mixed. In the thermocycled groups, all failure modes were adhesive in nature. Failure modes of water-stored Dentusil were $60 \%$ adhesive and $40 \%$ mixed. In the thermocycled groups, failure mode changed to $40 \%$ adhesive and $60 \%$ mixed. After shear testing, water-stored Mucopren Soft had $80 \%$ cohesive and $20 \%$ mixed failures, while in the thermocycled groups, the failure modes changed to $40 \%$ adhesive and $60 \%$ mixed. Water-stored MollosilPlusshear failure modes were $20 \%$ adhesive, $60 \%$ cohesive and $20 \%$ mixed. Following thermocycling, the proportions changed to $60 \%$ cohesive and $40 \%$ mixed. Water-stored Dentusil exhibited $20 \%$ adhesive, $60 \%$ cohesive and $20 \%$ mixed failure modes. However, in the thermocycled groups, failure modes changed to $20 \%$ adhesive, $40 \%$ cohesive and $40 \%$ mixed.

The results of the mechanical testing of resilient lining materials are important and help determining which materials have the better resistance under tensile or shear loading. In general, it was observed that the mechanical properties of all liners underwent some degradation after thermocycling. These results agree those previously published ${ }^{1,3}$.

The failure modes after mechanical testing (Table 4) suggest that when submitted to alternate temperature change and multidirectional forces in the mouth, Mollosil liner may undergo interfacial separation. Under the same conditions, both tear and interfacial separation may occur for Mucopren, while Dentusil liner may undergo cohesive or mixed separation.

The tensile bond strength means recorded in the present work are higher than those usually reported as clinically acceptable 2,9 . Craig and Gibbons ${ }^{2}$ (1961) claim that $0.44 \mathrm{MPa}$ is an adequate bond strength value for a soft liner, whereas Kawano, et al. ${ }^{5}$ (1992) suggest that the failure stress should be at least $0.96 \mathrm{MPa}$. Thus, comparing the tensile strength of the silicone liners used in the present study to these minimally acceptable values, all liner materials tested had bond strength for clinical use. The only exception was Mollosil-Plus after thermocycling, whose tensile strength $(0.81 \mathrm{MPa})$ is below this standard. Clinical studies should be conducted to complement these results.

The different behaviors of silicone-based soft liners may be related to their chemical properties. According to McCabe, et $\mathrm{al}^{7}$ (2002), depending on the type of solvent used, adhesion may be either enhanced or lessened. The 
polymerization technique influences the mechanical properties as well. According to Hekimuglu and Anil ${ }^{4}$ (1999), heat-cured acrylic resins are slightly better than autopolymerized resins.

There are a large variety of silicone-based liners on the market with excellent mechanical properties, much superior to those initially marketed. It should be emphasized that, although laboratory studies simulating clinical conditions have shown good adhesive characteristics, long-term clinical studies are needed to actually compare the materials and their classifications. Although only three commercial products were used in the present study, we believe that differences existing among the selected liners represent valid comparisons and may apply to similar products. An important issue is that when properly indicated and correctly handled by the technician, these materials achieve the goal for which they have been developed, providing comfort to the patients and leading to a more uniform stress distribution at the mucous/denture interface.

\section{CONCLUSIONS}

1. Thermocycling resulted in significant decrease in both tensile and shear bond strengths of silicone-based liners to an acrylic denture base resin.

2. Thermocycling changed the mode of failure to mixed failure.

3. Mucopren Soft may have a better clinical behavior than the other soft liners (Mollosil-Plus and Dentusil) because it had the highest tensile and shear strength of all materials under both tested conditions (water storage alone or thermocycling).

4. All silicone-based soft liners had higher bond strengths to the denture base resin acrylic resin than those reported as acceptable for clinical use.

\section{REFERENCES}

1- Braden M, Wright PS, Parker S. Soft lining materials: a review. Eur J Prosthodont Restor Dent. 1995;3:163-74.

2- Craig RG, Gibbons P. Properties of resilient denture liners. J Am Dent Assoc. 1961;63:114-9.

3- Garcia RCMR, Leon BLT, Oliveira VMB, Cury AAB. Effect of a denture cleanser on weight, surface roughness and tensile bond strength of two resilient denture liners. J Prosthet Dent. 2003;89:489-94.

4- Hekimuglu C, Anil N. The effect of accelerated aging on the mechanical properties of soft denture lining materials. J Oral Rehabil. $1999 ; 26: 745-8$

5- Kawano F, Dootz ER, Koran A, Craig RG. Comparison of bond strength of six soft denture liners to denture base resin. J Prosthet Dent. 1992;68:368-71.

6- Kulak-Ozkan Y, Sertgoz A, Gedik, H. Effect of thermo cycling on tensile bond strength of six silicone-based, resilient denture liners. J Prosthet Dent. 2003;89:303-10.
7- McCabe JF, Carrick TE, Kamohara H. Adhesive strength and compliance for denture soft lining materials. Biomaterials. $2002 ; 23: 1347-52$

8- Pinto JRR, Mesquita MF, Henriques GEP, Nobilo MAA. Effect of thermo cycling on bond strength and elasticity of 4 long-term soft denture liners. J Prosthet Dent. 2002;88:516-21.

9- Wright PS. Soft lining materials: their status and prospects. J Dent. $1976 ; 4: 247-56$. 